\title{
PLANO DE EMPREENDIMENTO: SEX BOUTIQUE
}

Recebido em 02.04.2017. Aprovado em 30.04.2017

Avaliado pelo sistema double blind review

\section{Barbara da Silva Nunes}

barbaranunes@id.uff.br

Departamento de Empreendedorismo e Gestão - Universidade Federal Fluminense - Niterói -RJ

\section{Sumário Executivo}

O presente Plano de Negócios apresenta uma empresa de sex shop. A Sex Boutique é uma empresa de pequeno porte que irá comercializar produtos eróticos e também oferecer serviços diferenciados. Junto à venda dos artigos, a empresa prestará consultoria sensual e visitas tirando dúvidas e resolvendo questões que rodeiam o cenário do mercado erótico. Organizações e exposições em eventos também farão parte das atividades desenvolvidas, e ainda para os casais que queiram deixar mais especial aquele momento à dois, a empresa ajudará com pacotes de decoração e climatização do ambiente. O mercado erótico brasileiro é um dos que mais crescem, em 2014 foi 8,5\%. A venda de artigos pela internet representa $52 \%$ do total de vendas no ano, seguido por $21 \%$ das consultorias domiciliares. Esses dados propicia alguns cenários favoráveis à implementação do negócio. Além do reconhecimento no mercado erótico, a empresa pretende se consolidar como a melhor opção de venda e distribuição de artigos eróticos de diversos tipos. E para chegar a esse patamar é necessário também conquistar a confiança e fidelidade de nossos clientes e parceiros. 0 relacionamento com o cliente será algo primordial para o melhor desenvolvimento das atividades da empresa. Através de um canal no YouTube os usuários podem tirar suas dúvidas e saber novas informações sobre os produtos. Sem esquecer também, da importância das redes sociais. No Plano Financeiro, a empresa apresenta números altos, a TIR (taxa interna de retorno) ultrapassa $800 \%$. Até porque os produtos variam muito de preço, o planejamento foi baseado em valores médios. Para o futuro, pretendese ampliar as instalações e concretizar os objetivos e metas traçados. Com o crescimento do faturamento, como previsto na projeção de vendas será necessário a contratação de novos profissionais para auxiliarem todo o crescimento e amparar nas transições.

Palavras-chaves: Plano de Empreendimento; SexBoutique; Sexshop; Empreendedorismo. 


\section{Apresentação da Empresa}

A Sex Boutique é uma empresa que comercializa produtos eróticos e também atua com a prestação de alguns serviços, através de promoções de eventos e consultoria para dúvidas dos clientes. À princípio, a venda será de forma e-commerce, sem a existência de uma loja física.

O objetivos dos eventos, feiras, chás de lingerie é promover um ambiente mais descontraído para tratar de um assunto que ainda deixa muitas pessoas sem graça, e assim, proporcionar um ambiente mais confortável. Há também a "customização" de locais, como em datas comemorativas, um aniversário de casamento, por exemplo, podendo um dos parceiros surpreender o outro.

Além destes serviços, a Sex Boutique se preocupa com a saúde sexual de seus clientes. Temos a intenção de levar a real informação sobre os nossos produtos através das nossas consultorias. Não basta apenas comprar um produto sem saber o que ele realmente faz e se o mesmo é seguro para a sua saúde e de seu parceiro(a).

Pretendemos levar o prazer até o cliente não somente através dos produtos, mas também junto a esses momentos que muitos não conseguem desfrutar. A discrição e a segurança do cliente fazem parte do nosso trabalho. Quanto mais confiante o cliente se sentir, mais satisfeitas estaremos.

Pensando em melhorar o contato com os clientes e deixá-los mais à vontade quanto este assunto, decidimos utilizar as mídias sociais a nosso favor. Começaremos por um canal no YouTube, onde divulgaremos dicas e informações, semanalmente, sobre determinados produtos, assim o cliente pode tirar suas dúvidas sem se expor. Além do nosso site e do canal, montaremos uma página no Facebook informando sobre as novidades do mercado e questões que envolvem a saúde da relação.

0 relacionamento com o cliente será o mais discreto possível, mas também de maneira prática. Podendo ele nos enviar e-mail com dúvidas e pedidos, e nós podendo responder publicamente através do canal. Como ferramenta para nos auxiliar utilizaremos o SAC 2.0, promovendo assim uma expansão e maior interação com o cliente e, buscando feedbacks espontâneos.

\section{Perfil do Empreendedor}

A empreendedora já teve uma breve experiência com o comércio de artigos eróticos na região onde mora. Há cerca de uns cinco anos ela e mais uma amiga vendiam produtos para colegas e conhecidos, indo até 0 cliente e mantendo um relacionamento diferenciado. Alguns produtos tinham disponível à pronta entrega, outros somente por encomenda. Isso era possível pois algumas das marcas comercializadas disponibilizam catálogos.

O preconceito e as questões culturais que cercam o negócio passam a ser um dos seus maiores desafios, ou seja, sua capacidade de oferecer ao mercado os melhores produtos e serviços e assegurar que a privacidade e a discrição sejam preservadas. A empreendedora colocará em seu processo de gerência sua breve experiência com as vendas dos artigos eróticos juntamente com suas habilidades e noções de gestão.

A importância pela busca de informações está atrelada à atividade de administrar. Esta consiste no processo de organizar 0 que foi planejado, assegurando a liderança e o controle da execução do trabalho. A empreendedora juntamente à profissionais qualificados, sexólogas e consultoras, buscaram levar as corretas informações aos clientes, organizando e monitorando os resultados alcançados.

\section{Descrição Legal}

A Sex Boutique iniciará suas atividades como micro empresa, administrada por uma única titular, sendo dessa forma classificada como EIRELI. E segundo o Classificação Nacional de Atividades Econômicas (CNAE) será enquadrada nas subclasses 4789-0/99 - COMÉRCIO VAREJISTA DE OUTROS PRODUTOS NÃO ESPECIFICADOS ANTERIORMENTE; e 8230-0/01 SERVIÇOS DE ORGANIZAÇÃO DE EVENTOS, EXCETO CULTURAIS E ESPORTIVOS, e terá o seu faturamento tributado pelo regime de competência, através do Simples Nacional. 


\section{Organização e Governança}

À princípio, a empresa iniciará suas atividades com duas consultoras, que também realizarão vendas. Toda parte relacionada a tomada de decisões financeiras, administrativas, entre outras áreas, será tomadas pela responsável. Futuramente, há planos para crescimento e desenvolvimento da empresa inserindo assim mais profissionais e novos processos de trabalho.

\section{Organograma}

O organograma da empresa, inicialmente será composto de maneira simples e à medida que o crescimento do negócio for acontecendo a empreendedora expandirá os demais cargos. A estrutura não terá forma hierárquica permitindo que haja interação e trabalho em equipe de todas as áreas. A titular da empresa será responsável pela gestão e acompanhamento das áreas de compras, vendas e distribuição. No futuro, pretende-se designar novos funcionários para se responsabilizar pelos departamentos de marketing, financeiro, controle de qualidade, entre outros.



Figura 1: Organograma

Fonte: Elaborada pela autora 


\section{Barbara da Silva Nunes}

\section{Quadros de funcionários atuais e futuros}

\begin{tabular}{|l|l|l|l|l|l|l|}
\hline Funcionários & $\begin{array}{l}\text { Consul- } \\
\text { tora }\end{array}$ & $\begin{array}{l}\text { Vende- } \\
\text { dora }\end{array}$ & Gerente & $\begin{array}{l}\text { Atendente } \\
\text { de relaciona- } \\
\text { mento }\end{array}$ & $\begin{array}{l}\text { Gestor } \\
\text { de distribuição }\end{array}$ & $\begin{array}{l}\text { Gestor de } \\
\text { Marketing }\end{array}$ \\
\hline Atuais & 2 & 2 & 1 & 1 & 0 & 0 \\
\hline Futuros & 4 & 4 & 2 & 3 & 1 & 1 \\
\hline
\end{tabular}

Quadro 1: Funcionários atuais e futuros

Fonte: Elaborado pela autora

\section{Principais processos de trabalho e atribuição de responsabilidades}

Os principais processos de trabalho serão a cotação de preços e qualidade dos produtos com os fornecedores, a compra dos produtos, a venda, o atendimento e relacionamento com cliente, o controle do armazenamento e distribuição, o serviço de consultorias e por fim o desenvolvimento do marketing da empresa. Estes processos irão atribuir responsabilidades ao utilizar a matriz $\mathrm{RACl}$, como segue o modelo abaixo:

- R: Responsável por executar uma atividade (o executor);

- A: Autoridade, quem deve responder pela atividade, o dono (apenas uma autoridade pode ser atribuída por atividade);

- C: Consultado, quem deve ser consultado e participar da decisão ou atividade no momento que for executada;

- I: Informado, quem deve receber a informação de que uma atividade foi executada.

Desta forma, o quadro abaixo designa cada processo de trabalho a um funcionário do estabelecimento.

\begin{tabular}{|l|l|l|l|l|l|l|}
\hline $\begin{array}{l}\text { Funcionários } \\
\text { /processos de } \\
\text { trabalho }\end{array}$ & $\begin{array}{l}\text { Consul- } \\
\text { tora }\end{array}$ & $\begin{array}{l}\text { Vende- } \\
\text { dora }\end{array}$ & Gerente & $\begin{array}{l}\text { Atendente } \\
\text { de relaciona- } \\
\text { mento }\end{array}$ & $\begin{array}{l}\text { Gestor de } \\
\text { distribuição }\end{array}$ & $\begin{array}{l}\text { Gestor de } \\
\text { Marketing }\end{array}$ \\
\hline $\begin{array}{l}\text { Cotação de } \\
\text { produtos }\end{array}$ & - & $I$ & R/A & - & - & - \\
\hline $\begin{array}{l}\text { Compra de } \\
\text { produtos }\end{array}$ & - & - & R/A & - & - & - \\
\hline
\end{tabular}




\begin{tabular}{|l|l|l|l|l|l|l|}
\hline Venda & - & R/A & I & - & I & - \\
\hline $\begin{array}{l}\text { Atendimento } \\
\text { relaciona- } \\
\text { mento }\end{array}$ & I & I & C & R/A & I & I \\
\hline $\begin{array}{l}\text { Controle } \\
\text { armazena- } \\
\begin{array}{l}\text { mento } \\
\text { distribuição }\end{array}\end{array}$ & - & I & C & - & R/A & - \\
\hline Consultoria & R/A & I & C & - & R & \\
\hline Marketing & - & - & C & I & - & - \\
\hline
\end{tabular}

\section{Quadro 2: Matriz RACI}

Fonte: Elaborado pela autora

\section{Estrutura física e layout}

A empresa trabalhará sem loja física, de forma e-commerce. No entanto, o Cadastro Nacional de Pessoas Jurídicas será feito com o endereço da residência da titular, até mesmo para que haja um local físico para armazenamento e distribuição dos produtos. A empresa trabalhará dentro dos meios legais com emissão de Notas Fiscais e controle financeiro. No futuro, há a possibilidade de expansão, o que prevê o aluguel de um espaço para controlar e administrar a demanda.

A marca da empresa será registrada pela sua discrição e conforto que irá propor aos clientes. Abaixo está o logo, o site ainda em construção e elaboração para melhor compreensão dos compradores.

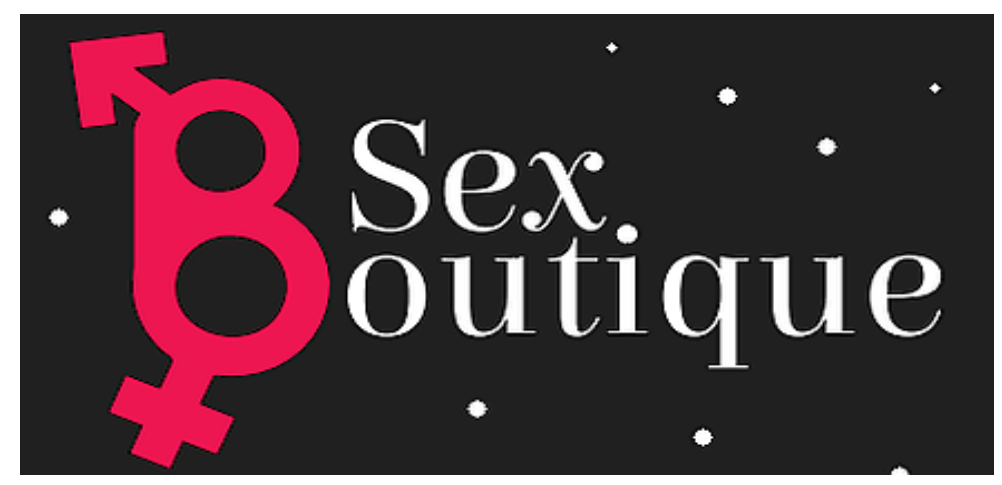

Figura 2: Logo Sex Boutique

Fonte: Elaborada pela autora 


\section{Benchmarking}

Foi realizado um processo de comparação entre os produtos e serviços ofertados pela empresa e os demais concorrentes. $O$ benchmarking do tipo competitivo foi utilizado para identificar os processos e gestão das empresas concorrentes, como o caso da Loja do Prazer. Abaixo é possível visualizar a imagem do site da empresa onde há uma boa alocação das informações fornecidas.

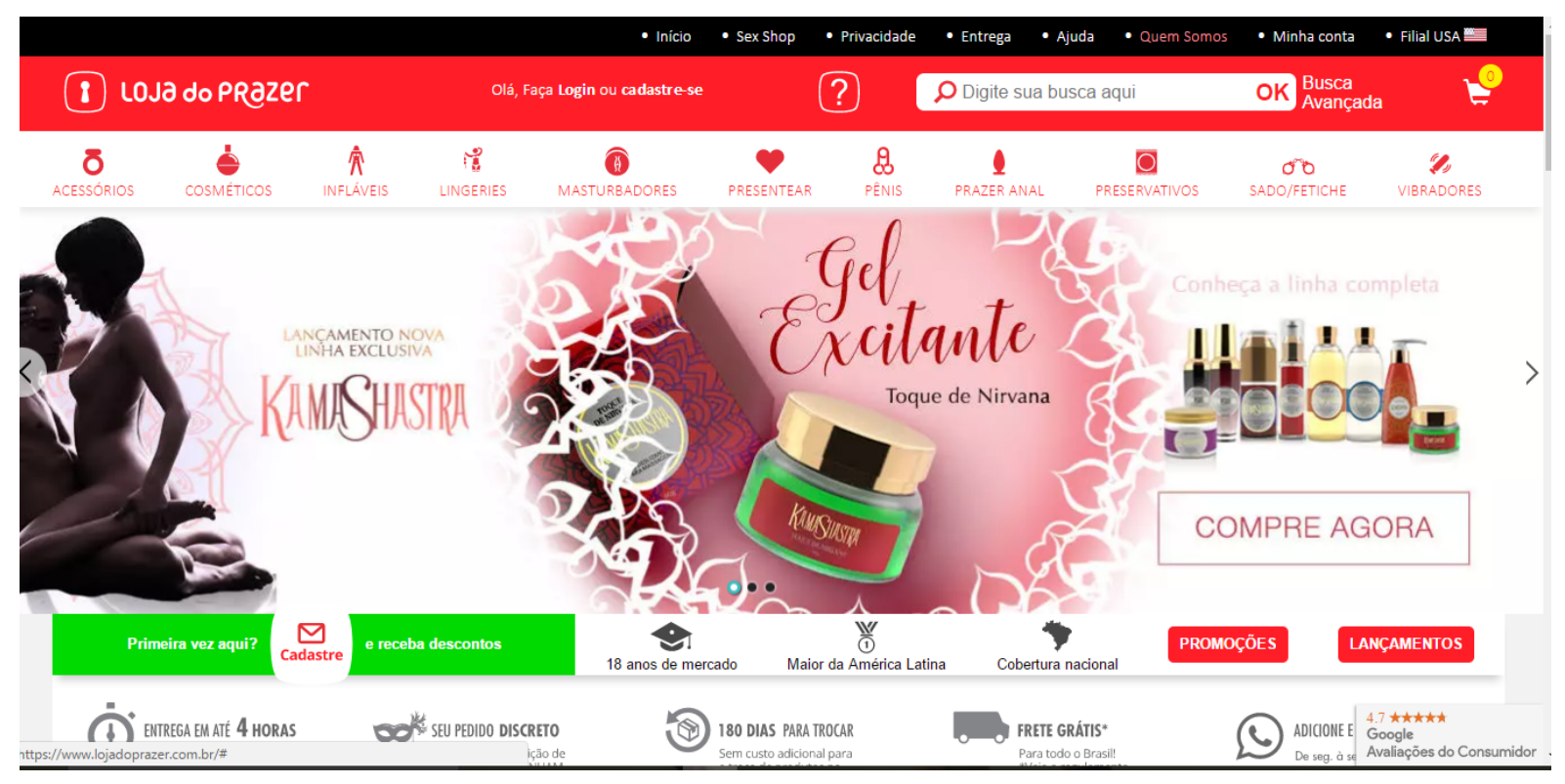

Figura 3: Site Loja do Prazer

Fonte: Loja do Prazer

\section{Análise de mercado}

O Brasil, atualmente possui diversos eventos, seminários e convenções no setor, (para negócios e consumidor final) estes são indicadores de que o consumo de produtos eróticos continua em alta no país,(8,5\% em 2014) mas tem muito ainda que crescer principalmente em relação ao consumo de países como os EUA e a Alemanha.

As empresas brasileiras injetam investimentos como nunca antes, tanto nos setores de produção e lançamento de novos produtos quanto em estratégias de publicidade e exportação de seus itens. No ano de 2014 , foram lançados mais de 50 novos produtos com variedade de aromas, cores e em diversas categorias que vão desde cosmética, lingeries sensuais até vibradores mais elaborados em sua matéria prima, e que com funções diferenciadas vêm crescendo em tecnologia.

Não se pode esquecer que o setor é responsável pela geração de (mais de 125 mil) empregos no país direta ou indiretamente, sendo que as mulheres são as maiores beneficiárias desta boa performance $(80 \%$ das vagas). Com um perfil diferenciado, de donas de casa até empresários, de operários das fábricas, costureiras a comerciantes em geral. Sem contar as minorias sexuais que encontram um campo sem preconceitos para o trabalho.

A importação já divide com os produtos nacionais a preferência dos consumidores $(47 \%$ dos itens comercializados nos pontos de venda). 0 produto brasileiro vem apresentando um crescimento significativo nas vendas ano após ano e em 2011 superou pela primeira vez o comércio de importados. O potencial fabril (mais de 50 empresas nacionais), tem sua especialização em próteses com e sem vibradores, acessórios, vestuário sensual e muita cosmética. O maior fabricante de produtos eróticos brasileiro, a Hot Flowers (3,5 milhões de itens / mês), comercializa desde cosméticos até vibradores coloridos. Exportando para a América 
do sul, África e Europa, a marca tem se firmado como uma das mais importantes do mundo.

A divisão dos negócios no Brasil por região em o domínio do sudeste que responde pela maior concentração de estados com negócios atuantes e de sucesso. O Estado de São Paulo lidera as vendas (33\% do total), seguido de MG, BA, RJ e RS.

Pode-se dizer que as economias em escala, empresas já estabelecidas no mercado e que produzem grandes quantidades, são barreiras à entrada uma vez que, forçam os novos competidores a produzirem e/ou venderem em enormes quantidades para evitarem custos mais elevados que os seus pares.

Uma outra barreira à entrada é a necessidade de capital. Um dos grandes fatores para destaque no mercado erótico são as empresas que investem em P\&D e a necessidade de investimentos não costuma ser baixa.

Durante alguns anos, a empreendedora vendeu estes tipos de artigos indo até o cliente, no município onde reside, Guapimirim, assim o mesmo se sentia mais à vontade. Aproveitando essa experiência, e notando a grande demanda da região, resolveu retornar com os produtos e trazer novidades.

A localização favorece o negócio de serviços, devido a ausência de empresas que exerçam esse tipo de atividade. Na cidade não há motel, ou algum estabelecimento do tipo. Isto pode ser uma vantagem, visto que posso ser a primeira a empreender no mercado erótico da região. Há pessoas que vendem de boca-aboca certos produtos. Mas a SEX BOUTIQUE será um pouco diferente, além do boca a boca, trabalharemos com qualidade em produtos e serviços, sendo a discrição e satisfação nossas principais aliadas.

A carência do mercado em empresas do ramo e que forneçam confiança e descrição é muito grande, e não somente no município, mas sim em todo país de maneira geral. Quando o assunto é o mercado erótico, a maioria das pessoas não se sentem muito à vontade de comentar e infelizmente ainda há muito preconceito a respeito do assunto. ${ }^{1}$

\section{Breve análise de Mercado e estratégias de segmentação}

A dimensão a ser seguida será a segmentação por comportamento, assim poderá dividir o mercado em grupos de acordo com o conhecimento e comportamento de consumo para um produto particular. Desta forma, é possível definir o grau de lealdade do cliente, a taxa de uso do produto entre outros divisões.Para melhor segmentar o mercado iremos direcionar nossas atividades à pessoas entre 18 e 45 anos, em geral Classe $B$, que gasta razoavelmente com produtos, tendo suas preferências para as fantasias e artigos comestíveis. Quando trata-se da consultoria, a faixa etária entre 46 e 60 anos correspondem às expectativas, pois muitos não vão a uma loja física.

A estratégia adotada será pautada na oferta de diferentes produtos objetivando ampliar o público alcançado no nosso mercado-alvo.

\section{Descrição do público-alvo}

Segundo a ABEME (Associação Brasileira das Empresas do Mercado Erótico e Sensual), o perfil de consumidores de produtos eróticos engloba tanto homens como mulheres. Na internet o público feminino é ligeiramente maior, corresponde a 55\%. A faixa etária dos consumidores é de 18 a 25 anos (43\%), 26 a 35 anos(36\%) e de mais de 35 anos (21\%).

A classe $B$ é a que mais compra pela internet. Esse público gosta mais de ofertas do que de lançamentos e é o que mais faz pesquisas antes de comprar.

$O$ público-alvo será direcionado à pessoas entre 18 e 45 anos, pertencentes às classes $B$ e $C$, que residem no Estado do Rio de Janeiro e que compram pela Internet.

\footnotetext{
${ }^{1}$ As informações desta seção foram retiradas de: https://www.abeme.com.br/publicacoes old/dados-estatisticos/ Acesso em: 01/04/2017
} 


\section{Análise da concorrência}

Para muitos empreendedores do ramo do mercado erótico a concorrência pode ser algo benéfico ao negócio. No entanto, quando a empresa atua no universo digital não se pode dizer o mesmo. A internet permite que qualquer pessoa tenha acesso a todo e qualquer tipo de produto, sem contar a privacidade e praticidade da compra. Desta forma, é possível afirmar que há um nível alto de concorrência no mercado erótico pela internet. Não é a toa que este meio representa $52 \%$ do crescimento do mercado.

Outra forma de concorrência, que nos últimos cinco anos vem ganhando destaque, principalmente após 0 lançamento do filme "De Pernas pro Ar" é a consultoria domiciliar. O número de pessoas que vendem nas sua próprias casas ou "de porta em porta" se eleva a cada ano e também possui uma parcela de $21 \%$ do crescimento do mercado.

Como resposta aos concorrentes a Sex Boutique tem como objetivo levar o que há de mais novo ao cliente, além de ser confortável e prazeroso. A satisfação do cliente será primordial, tanto quanto ao consumo dos produtos quanto aos eventos e "decorações" que iremos fazer. Por exemplo, numa data especial como dias dos namorados ou aniversário de casamento um dos parceiros pode resolver surpreender o outro e contar com a nossa ajuda, seja com uma bela cesta de café da manhã ou uma noite diferente, com flores frescas, um bom vinho e entre outros artefatos para tornar ainda mais especial aquele momento.

Temos como diferencial essa "consultoria amorosa", indo até o cliente, deixando-o mais à vontade para falar de assuntos eróticos e até mesmo quebrando certos tabus quanto ao assunto. Para nós esses momentos precisam e são muito especiais, pois não importa somente o comércio e consumo de produtos e sim a saúde sexual e mental das pessoas.

\begin{tabular}{|l|l|l|l|}
\hline Informações & $\begin{array}{l}\text { Concorrente 1: } \\
\text { Loja do Prazer }\end{array}$ & $\begin{array}{l}\text { Concorrente 2: } \\
\text { Miess }\end{array}$ & Sex Boutique \\
\hline Atuação & Brasil - EUA & Brasil & Brasil - foco RJ \\
\hline Público-alvo & $\begin{array}{l}50 \% \text { pessoas físicas; } \\
50 \%\end{array}$ & $\begin{array}{l}90 \% \text { consultoras; } \\
10 \% \text { lojas físicas } \\
\text { jurídicas pessoas }\end{array}$ & $\begin{array}{l}50 \% \text { consultoras; } \\
50 \% \text { lojas físicas }\end{array}$ \\
\hline Pontos Fortes & $\begin{array}{l}\text { Qualidade, variedade } \\
\text { e preço justo }\end{array}$ & $\begin{array}{l}\text { Modernidade, } \\
\text { excelência } \\
\text { compromisso com } \\
\text { consumidor }\end{array}$ & $\begin{array}{l}\text { Qualidade, } \\
\text { modernidade } \\
\text { variedade, discrição e } \\
\text { excelência. }\end{array}$ \\
\hline Pontos Fracos & Não identificados & $\begin{array}{l}\text { Pouca visualização da } \\
\text { marca }\end{array}$ & $\begin{array}{l}\text { Pouca experiência no } \\
\text { mercado }\end{array}$ \\
\hline Estratégias utilizadas & $\begin{array}{l}\text { Atendimento } \\
\text { excelente e entrega } \\
\text { rápida }\end{array}$ & $\begin{array}{l}\text { E-business } \\
\text { consolidação da marca e } \\
\text { aumento das vendas }\end{array}$ & $\begin{array}{l}\text { Atendimento } \\
\text { diferenciado, uso das } \\
\text { mídias sociais para } \\
\text { melhor relacionamento } \\
\text { com os clientes. }\end{array}$ \\
\hline
\end{tabular}


Quadro 3: Análise da Concorrência

Fonte: Elaborado pela autora com informações dos sites concorrentes (Loja do Prazer e Miess)

\section{Descrição dos possíveis fornecedores}

As principais transações ocorrem com os maiores e diferenciados fornecedores de artigos eróticos situados em São Paulo e Rio Grande do Sul. Para também se manter atualizada, além de aumentar a variedade dos produtos, também é possível realizar transações com fornecedores estrangeiros. Mas tanto para as transações nacionais quanto as internacionais é essencial que haja um contato pessoal esporadicamente, assim as relações de confiança e credibilidade estão sempre renovadas.

Além destes tipos de fornecedores, também há os fornecedores sazonais que são escolhidos de acordo com o preço e a qualidade. Uma das formas de descobrir novos fornecedores e de confiança é através da Erotika Fair a maior feira de artigos eróticos do país. Na feira é possível ficar sabendo de vários lançamentos e novidades do mercado.

Abaixo está listado alguns dos fornecedores e respectivos produtos fornecidos por eles:

\begin{tabular}{|l|l|}
\hline Tipo de Produto & Fornecedor \\
\hline $\begin{array}{l}\text { Acessórios (anéis penianos, estimuladores, } \\
\text { capas penianas, massageadores, etc) }\end{array}$ & $\begin{array}{l}\text { Hot Flowers, Diversão ao Cubo, Mix Collection, K } \\
\text { Import e Export; }\end{array}$ \\
\hline Cosméticos & Hot Flowers, Dados Eróticos \\
\hline Lingeries & Miss Collection, Mirage Lingerie \\
\hline Masturbadores e vibradores & Desire,Sexy Fantasy \\
\hline
\end{tabular}

Quadro 4: Fornecedores

Fonte: Elaborado pela autora
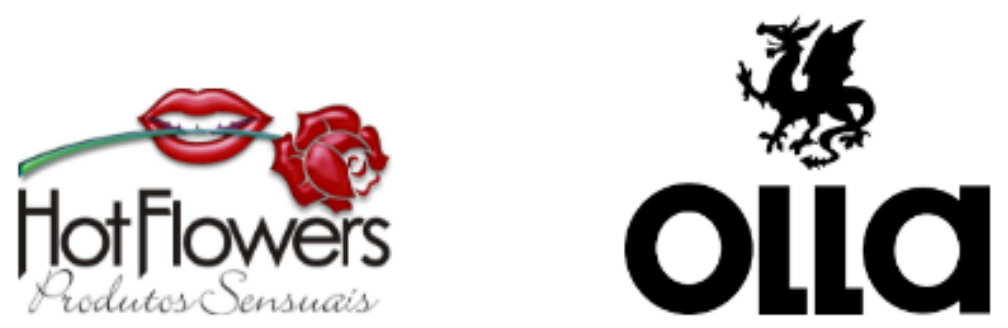

\section{LELO}
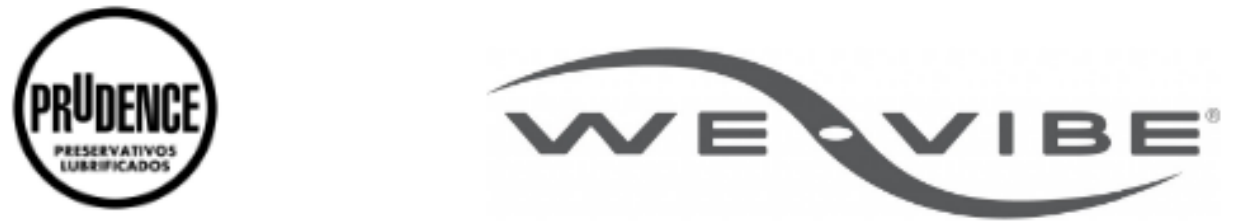

Figura 4: Marcas de fornecedores

Fonte: Imagens retiradas do Google pela autora 


\section{Plano estratégico}

\section{Missão, Visão e Valores}

A missão da empresa, segundo Dornelas (2001, p.155) é razão dela existir, o que ela é e o que ela faz e a da Sex Boutique é proporcionar mais prazer, promover a saúde mental e sexual, oferecendo produtos e serviços de qualidade aos nossos clientes.

A visão é alcançar a excelência e nos tornar referência no mercado onde atuamos, através da satisfação das necessidades do universo sexual.

Os nossos valores são: Clientes, Ética, Respeito, Parceria, Discrição, Honestidade e Comprometimento.

\section{Análise SWOT}



Figura 5: Matriz SWOT

Fonte: Elaborado pela autora

Ambiente Interno

- Pontos Fortes

$\rightarrow$ Variedade de produtos: grande número de produtos para satisfazer todos os tipos de clientes.

$\rightarrow$ Serviço de entrega: vendas e entregas online e por telefone dão mais conforto e discrição ao cliente.

$\rightarrow$ Possuir um site: o site oferece mais privacidade e discrição ao cliente.

$\rightarrow$ Estoque: 0 grande estoque dá maior segurança para o estabelecimento garantindo que não faltem produtos. 
$\rightarrow$ Organização de eventos: eventos como palestras, chá de lingerie, despedidas de solteiro, comemorações de datas especiais entre outros, agregam mais valor.

$\rightarrow$ Consultoria sobre saúde sexual: a preocupação com a saúde sexual dos clientes desperta o interesse de novos consumidores.

$\rightarrow$ Venda direta: por não possuir loja física, as vendas podem ocorrer com o contato direto com o cliente 0 que passa mais confiança e segurança.

\section{- Pontos Fracos:}

$\rightarrow$ Compra de produtos e não produção: a ausência da própria fabricação e desenvolvimento de produtos pode ser desvantagem visto os maiores concorrentes.

$\rightarrow$ Tamanho da equipe: por ser uma empresa pequena, possui poucos funcionários o que pode fazer com uma mesma pessoa desenvolva várias funções.

$\rightarrow$ Capacidade de estoque: por não possuir um espaço físico, a capacidade de armazenamento dos produtos fica comprometida, sendo necessário um planejamento a médio e longo prazo.

$\rightarrow$ Poder de compra e negociação com fornecedores: devido a iniciação tardia da empresa ao mercado, o poder de compra, ou seja, o crédito para realizar compras com os fornecedores torna-se menor ou quase nenhum, tendo em vista que com o tempo a empresa conquistará a confiança e preferência de seus fornecedores.

$\rightarrow$ Entrada tardia no mercado: há muitas outras empresas inseridas no mercado há anos, principalmente com grande volume de vendas online.

\section{Ambiente externo}

\section{- Oportunidades}

$\rightarrow$ Economia: o mercado erótico está em constante crescimento. O Brasil comercializa cerca de 9 bilhões de itens por mês ${ }^{2}$, e ainda é referência mundial em lingerie sexy. Segundo a Abeme, o Rio de Janeiro é o segundo Estado que mais vende pela internet, representando $16 \%$ do total de produtos comercializados em todo o país. Além disso, a presidente da Abeme, Paula Aguiar, afirmou um crescimento de $3 \%{ }^{3}$ no mercado erótico brasileiro em 2016, ou seja, apesar da crise o mercado ainda se mantém crescendo mesmo que de forma pequena.

$\rightarrow$ Tecnologia: os canais de distribuição são aliados do negócio, a internet é um dos que mais cresce no setor, representando $52 \%$ das vendas, seguido da consultoria domiciliar que engloba $21 \%$. Além da privacidade e discrição, a internet possui uma maior abrangência e coloca à disposição dos consumidores um canal mais democrático e interativo.

$\rightarrow$ Erotika Fair: esta é a quarta feira mais visitada do mundo, podendo assim se manter atualizada quanto ao mercados e aos produtos, além de estabelecer novas relações com fornecedores.

\footnotetext{
${ }^{2}$ As informações desta seção foram retiradas de: https://www.abeme.com.br/release-abeme-2017-informacoesnumeros-e-dados-oficiais/

Acessado em: 08/06/2017

${ }^{3}$ A informação desta seção está disponível em:https://www.abeme.com.br/publicacoes old/timeline/ Acessado em : 08/06/2017
} 
$\rightarrow$ Busca de parcerias com motéis: alguns motéis vendem produtos eróticos em seus quartos. Esse tipo de parceria aumenta o número de vendas e área de atuação.

$\rightarrow$ Busca por novas parcerias: como a empresa trabalhará com a elaboração e customização de eventos é bom possuir parcerias com floriculturas, bombonieres entre outros.

$\rightarrow$ Crescimento das redes sociais: A empresa pode utilizar do sucesso das redes sociais para divulgar cada vez mais seu nome e conquistar novos consumidores, além de manter um melhor relacionamento com 0 cliente.

$\rightarrow$ Comunicação fraca do mercado erótico: a maioria dos sex-shops possui comunicação pouco criativa e atrativa, podendo fazer com que nós com uma divulgação mais elaborada, ganhe destaque em relação aos seus concorrentes.

\section{- Ameaças}

$\rightarrow$ Tabu e cultura conservadora: apesar da queda no número de fiéis das diversas religiões, $89 \%$ dos brasileiros concordam que a religião é de suma importância em suas vida ${ }^{4}$. A cultura e a crença da população podem influenciar negativamente o consumo de produtos eróticos, pois muitos se posicionam contra as variações e excessos na vida sexual. Além do mais, ainda há muitas pessoas com receio de entrarem num estabelecimento de sex shopping, o pudor e o preconceito ainda acompanham 0 assunto.

$\rightarrow$ Fornecedor desleal: um grande fornecedor nacional de produtos eróticos, criou um site em que vende produtos para o consumidor final a preço de atacado, podendo roubar clientes de outras sex-shops.

$\rightarrow$ Sex-shops virtuais: a facilidade e a discrição de se comprar produtos eróticos na Internet, muitas vezes com preços menores, possibilitam o surgimento de novos tipos de concorrentes. Além disso, essa concorrência não possui limites territoriais, permitindo a aquisição de produtos de outros estados, ou até mesmo, países.

$\rightarrow$ Associação de Sex-shops à prostituição: como existem estabelecimentos que gerenciam garotas de programa, as sex-shops, acabam sendo mal vistas pela sociedade.

$\rightarrow$ Aumento dos divórcios e queda no número de casamentos: com o posicionamento do cliente voltado para os casais, essas estatísticas afetam diariamente a fatia da população considerada público-alvo pela empresa.

$\rightarrow$ Número de estabelecimentos cresce mais do que os consumidores: nos últimos anos, o mercado erótico brasileiro apresentou um crescimento considerável. Porém, o consumo não acompanhou o aumento da quantidade de lojas proporcionalmente.

Plano de ação: objetivos, metas e indicadores de ações estratégicas

\begin{tabular}{|l|l|l|}
\hline OBJETIVOS & METAS & INDICADORES \\
\hline $\begin{array}{l}\text { Ser reconhecida no mercado } \\
\text { erótico pelo seu serviço } \\
\text { diferenciado. }\end{array}$ & $\begin{array}{l}\text { Prestar serviços de consultoria } \\
\text { domiciliar levando } \\
\text { conscientização sobre a saúde } \\
\text { sexual do usuário. }\end{array}$ & $\begin{array}{l}\text { Aumento do número de } \\
\text { contratações dos serviços a } \\
\text { cada semestre. }\end{array}$ \\
\hline $\begin{array}{l}\text { Consolidar como a melhor } \\
\text { opção de venda e distribuição }\end{array}$ & $\begin{array}{l}\text { Realizar além da venda online, } \\
\text { a venda direta e oferecer }\end{array}$ & $\begin{array}{l}\text { Crescimento do número de } \\
\text { visitas no primeiro ano de }\end{array}$ \\
\hline
\end{tabular}

\footnotetext{
${ }^{4}$ A informação desta seção está disponível em:http://www.cps.fgv.br/cps/religiao/ Acessado em: 08/06/2017
} 


\begin{tabular}{|l|l|l|}
\hline $\begin{array}{l}\text { de todo tipo de produto erótico e } \\
\text { sexual. }\end{array}$ & produtos novos e inovadores. & empresa. \\
\hline $\begin{array}{l}\text { Conquistar a confiança e } \\
\text { credibilidade de nossos clientes } \\
\text { e parceiros. }\end{array}$ & $\begin{array}{l}\text { Vender somente produtos de } \\
\text { qualidade e certificados. }\end{array}$ & $\begin{array}{l}\text { Acompanhar o nível de } \\
\text { sugestões reclamações dos } \\
\text { clientes. }\end{array}$ \\
\hline
\end{tabular}

Quadro 5: Objetivos, metas e indicadores

Fonte: Elaborado pela autora

Como citado nos objetivos acima, a Sex Boutique tem como objetivo ser reconhecida no mercado erótico pelo seu serviço diferenciado, e esse reconhecimento começa a partir do meio digital, onde o número de vendas é maior. Como primeira ação estratégica teremos a ampliação do alcance de vendas na internet. É preciso que os consumidores saiba quem somos, reconheça nossa marca.

Outra ação para melhorar o desenvolvimento de nossas atividades, será o treinamento e capacitação. Investimento em pessoas nunca é demais, e com o crescimento da empresa se faz necessário um progresso em nossos serviços.

\begin{tabular}{|c|c|c|}
\hline "WHAT" O quê? & $\begin{array}{l}\text { Ampliação do alcance de vendas na } \\
\text { internet. }\end{array}$ & $\begin{array}{l}\text { Treinamento e capacitação das } \\
\text { consultoras. }\end{array}$ \\
\hline "WHO" Quem? & A empreendedora. & Consultoras \\
\hline "WHERE" Onde? & $\mathrm{Na}$ internet. & Na própria empresa. \\
\hline "WHEN" Quando? & No primeiro ano de empresa. & No primeiro ano de empresa. \\
\hline "WHY" Por quê? & Para conquistar e fidelizar clientes. & $\begin{array}{l}\text { Para melhorar a qualidade do serviço } \\
\text { e acompanhar o crescimento. }\end{array}$ \\
\hline "HOW" Como? & $\begin{array}{l}\text { Promovendo atrativos, como } \\
\text { promoções, anúncios, parcerias } \\
\text { com outros sites. Dando mais } \\
\text { visibilidade a empresa e deixando } \\
\text { com que as pessoas a identifique. }\end{array}$ & $\begin{array}{l}\text { Por meio de palestras, workshops, } \\
\text { auxílio de profissionais da área } \\
\text { (sexólogas). }\end{array}$ \\
\hline $\begin{array}{l}\text { "HOW } \\
\text { Quanto? }\end{array}$ & $\begin{array}{l}\text { Investimentos com marketing e } \\
\text { publicidade podem ser a partir de } R \$ \\
1.000,00 \text {. }\end{array}$ & $\begin{array}{l}\text { Os custos com investimentos em } \\
\text { profissionais podem variar, de acordo } \\
\text { com a disponibilidade de procura do } \\
\text { mesmo. }\end{array}$ \\
\hline
\end{tabular}

Quadro 6: Ações estratégicas

Fonte: Elaborado pela autora 
Modelo de negócios

\begin{tabular}{|c|c|c|c|c|c|}
\hline \multirow{3}{*}{$\begin{array}{l}\text { PARCEIROS CHAVEs } \\
\text { - Consultoras } \\
\text { Sensuais; } \\
\text { - Floriculturas; } \\
\text { - Lojas atacadistas } \\
\text { online; } \\
\text { - Fabricantes ou } \\
\text { importadores; } \\
\text { - Desenvolvedor Web; } \\
\text { - Correios; } \\
\text { - Docerias; } \\
\text { - Profissionais do } \\
\text { setor (sexólogas); } \\
\text { - Sistema de Gestão } \\
\text { online; } \\
\text { - Blogs, Portais ou } \\
\text { revistas atualizadas. }\end{array}$} & $\begin{array}{l}\text { ATUVIDADES } \\
\text { CHAVES }\end{array}$ & \multirow{3}{*}{\multicolumn{2}{|c|}{$\begin{array}{l}\text { PREPOSIçõEs DE } \\
\text { VALOREs } \\
\text { - Atendimento } \\
\text { personalizado; } \\
\text { - Melhorar a qualidade } \\
\text { de vida; } \\
\text { - Preocupação com a } \\
\text { saúde sexual do } \\
\text { usuário; } \\
\text { - Celebrar datas } \\
\text { especiais com o } \\
\text { parceiro; } \\
\text { - Divertir e apimentar a } \\
\text { relação do casal; } \\
\text { - Serviço diferenciado. }\end{array}$}} & $\begin{array}{l}\text { RELACIONAMENTO } \\
\text { COM CLIENTES }\end{array}$ & \multirow{3}{*}{$\begin{array}{l}\text { SEGMENTOS DE } \\
\text { CLIENTES } \\
\text { - Homens e mulheres; } \\
\text { - Classes A, B e C; } \\
\text { - Entre } 18 \text { a } 45 \text { anos. }\end{array}$} \\
\hline & $\begin{array}{l}\text { - Mix de produtos; } \\
\text { - Vendas online; } \\
\text { - Vendas diretas; } \\
\text { - Criação de conteúdo } \\
\text { sobre a vida sexual; } \\
\text { - Gestão do site e } \\
\text { logística. }\end{array}$ & & & $\begin{array}{l}\text { - Indicação de uso dos } \\
\text { produtos; } \\
\text { - Utilização de redes } \\
\text { sociais, email, contato } \\
\text { direto; } \\
\text { - Dicas para melhorar a } \\
\text { vida sexual. }\end{array}$ & \\
\hline & $\begin{array}{l}\text { RECURsos } \\
\text { CHAUEs } \\
\text { - Mão de obra } \\
\text { qualificada; } \\
\text { - Website, marca; } \\
\text { - Conhecimentos da } \\
\text { sexualidade humana; } \\
\text { - Fornecedores } \\
\text { certificados. }\end{array}$ & & & $\begin{array}{l}\text { CANAls } \\
\text { - Site; } \\
\text { - Correios; } \\
\text { - Consultoras sensuais; } \\
\text { - Entrega direta. }\end{array}$ & \\
\hline \multicolumn{3}{|c|}{$\begin{array}{l}\text { custos } \\
\text { - Produtos (estoque) e logística; } \\
\text { - Manutenção e melhorias no site; } \\
\text { - Marketing digital e de conteúdo; } \\
\text { - Seleção e treinamento das consultoras sensuais. }\end{array}$} & \multicolumn{3}{|c|}{$\begin{array}{l}\text { RECEITAS } \\
\text { - Clientes preferem pagar com cartão; } \\
\text { - Vendas de produtos eróticos; } \\
\text { - Não há valor limite para receita, é de acordo com o } \\
\text { volume de vendas; } \\
\text { - Valor: qualidade. }\end{array}$} \\
\hline
\end{tabular}

Figura 6: Modelo Canvas

Fonte: Elaborado pela autora

\section{Marketing e Vendas}

\section{Descrição detalhada do produto/serviço}

0 estoque de produtos eróticos é bem extenso. Abaixo está o exemplos de alguns dos muitos artigos que serão comercializados pela Sex Boutique.

$\rightarrow$ Acessórios: anéis penianos, capas e extensores penianos, cintas penianas, desenvolvedores penianos, estimuladores e dedeiras, livros eróticos, massageadores eróticos, pompoarismo, tapamamilos, universo feminino;

$\rightarrow$ Cosméticos: bolinhas de óleos corporais, canetas para o corpo, comestíveis, corpo e banho, energético afrodisíaco, excitantes unissex, garganta profunda, géis femininos, géis hot para massagem, géis ice para massagem, géis para beijar/sexo oral, géis para sexo anal, géis retardantes, loções para masturbação, lubrificantes à base de água, lubrificantes, lubrificantes à base de silicone, perfumes afrodisíacos, suplementos afrodisíacos, talco afrodisíaco comestível, velas para massagem, vibrador líquido;

$\rightarrow$ Infláveis: bonecas, bonecos e travestis;

$\rightarrow$ Lingeries: baby dolls, bodies, calcinhas com abertura, calcinha caleçon, calcinhas fio-dental, camisolas, conjuntos sensuais, corseletes, cuecas sensuais, espartilhos, fantasias (empregada, enfermeira, estudante, mamãe noel, noiva, super herói), fantasias eróticas femininas, macacões sensuais, vestidos sensuais; 
$\rightarrow$ Masturbadores: masturbadores masculinos (Egg Tenga), vaginas, ânus e bocas;

$\rightarrow$ Presentes: baralhos eróticos, dadinhos eróticos, móveis eróticos, presentes eróticos, presentes românticos;

$\rightarrow$ Pênis: imitam pele humana, importados, importados com vibro, até $12 \mathrm{~cm}, 13 \mathrm{a} 15 \mathrm{~cm}, 13$ a $15 \mathrm{~cm}$ com vibro, 16 a $18 \mathrm{~cm}, 16$ a $18 \mathrm{~cm}$ com vibro, 19 a $21 \mathrm{~cm}, 19$ a $21 \mathrm{~cm}$ com vibro, 22 a $24 \mathrm{~cm}, 22$ a $24 \mathrm{~cm}$ com vibro, acima de $25 \mathrm{~cm}$, acima de $25 \mathrm{~cm}$ com vibro, pênis duplos, pênis duplos com vibrador;

$\rightarrow$ Prazer anal: bolinhas, duchas higiênicas, estimuladores de próstata, géis para sexo anal, lubrificantes, preservativos e plugs anais;

$\rightarrow$ Preservativos: preservativos com sabor, preservativos retardantes, preservativos $\mathrm{XL}$, preservativos super finos e outros preservativos;

$\rightarrow$ Sadomasoquismo/Fetiche: acessórios, algemas, anéis penianos sado, arreios sado, chibatas e chicotes, coleiras e mordaças, kits bondage, prendedores de mamilos, vendas, capuzes e máscaras;

$\rightarrow$ Vibradores: a "famosa" borboleta, calcinhas com vibrador, cápsulas/bullets, carregados via USB, cinta/butterflies, clássicos/personais, com controle remoto, estimulação dupla, higienizadores para vibrador, o "famoso" rabbit, para estimular o clitóris, rabbits/rotativos, simulador de sexo oral, sugador de clitóris, vibradores de silicone, vibradores disfarçados, vibradores femininos, vibradores para o casal, vibradores ponto $\mathrm{G}$.

Quanto aos serviços, haverá apresentações dos produtos em feiras e eventos, chá de lingeries, despedidas de solteiro. Consultoria onde será possível o clientes tirar suas dúvidas quanto ao uso, qualidade dos produtos e prevenção à males contra a saúde sexual.

\section{Descrição da inovação trazida pela empresa}

A empresa irá oferecer serviços diferenciados, propiciando a discrição e a privacidade aos clientes. Através das consultorias virtuais e de eventos os usuários poderão tirar suas dúvidas e conhecer todas as novidades do mercado erótico, ou seja, o objeto da inovação trazido pela empresa será o processo. Esta modificação propicia um atendimento diferenciado e um bom relacionamento com cliente, não se trata de algo absurdamente novo, será um aperfeiçoamento, um incremento a algo que já existe mas que a Sex Boutique vai proporcionar aos usuários.

Além dos serviços citados acima, os clientes da Sex Boutique terão acesso à artigos inovadores, o que beneficia a sociedade como um todo, novidades do mercado erótico mundial, onde poderão também ter mais consciência sobre a sua saúde sexual. A direção de esforço desta inovação é de maneira sustentada, mantendo a lógica do mercado, promovendo discrição e segurança à quem utiliza os produtos, fazendo com que as pessoas se sintam mais à vontade em tratar do assunto.

\section{Propriedade intelectual e/ou formas de evitar imitações}

Há várias formas de imitações deste tipo de negócio, justamente porque o mercado está em constante crescimento. $O$ surgimento de sex shops online é cada vez mais facilitado devido a acessibilidade de todos a diversos de tipos de fornecedores pela internet. Uma das formas de não ser imitado, é trabalhar com diferencial, com qualidade. É conquistar a credibilidade do cliente, assegurá-lo que toda venda haverá discrição e privacidade, que os produtos que são comercializados possuem certificação de qualidade, e que a Sex Boutique se preocupa com a saúde e bem estar dos seus clientes. 


\section{Barbara da Silva Nunes}

\section{Evolução prevista do produto - pesquisa e desenvolvimento}

Os produtos mais vendidos, segunda a presidente da Abeme, são os que estão relacionados ao sexo oral, representando $21 \%$ das venda do mercado erótico brasileiro. Seguindo estão os vibradores, com 18\% e cremes e pomadas para o sexo anal junto a cápsulas de banho, com $11 \%$ cada.

O crescimento do mercado é notório, mas há ainda pouco desenvolvimento quanto à fabricação e pesquisa de produtos destinados ao sadomasoquismo. O sadomasoquismo é a relação entre duas tendência de busca por prazer: o sadismo e o masoquismo. O primeiro é a busca do prazer impondo sofrimento físico e moral a outra pessoa e o masoquismo é a busca por prazer de forma oposta, recebendo o sofrimento físico e moral praticado por outra pessoa.

Após o lançamento do livro Cinquenta Tons de Cinza, os artigos de sadomasoquismo ganharam mais destaque, mas ainda assim é pequeno o número de fabricantes e pesquisadores de novos e melhores produtos do tipo.

Um dos objetivos da empresa é se "aproximar" mais de seus clientes, aperfeiçoar nossos serviços, através um atendimento diferenciado e de um contato diferente. 0 canal no YouTube auxiliará essa conexão promovendo uma maior interação com as pessoas, permitindo que tirem suas dúvidas e desenvolva o nosso conceito, que é levar conscientização sobre a saúde sexual.

\section{Comparação com produtos substitutos e/ou concorrentes}

A empresa trabalhará com um serviço diferenciado, o que pode se destacar frente aos seus concorrentes. A consultoria, as visitas, apresentação em feiras e eventos, além de organização de chás de lingeries, entre outros, contribuirá muito para o crescimento do negócio.

Os concorrentes mais fortes estão situados no universo digital, o que nos forçar a buscar cada vez mais alcance e reconhecimento de nossos clientes, garantindo a qualidade e satisfação.

\begin{tabular}{|l|l|l|l|l|l|}
\hline $\begin{array}{l}\text { Fatores críticos / } \\
\text { concorrência }\end{array}$ & Qualidade & Preço & $\begin{array}{l}\text { Canais de } \\
\text { venda }\end{array}$ & $\begin{array}{l}\text { Variedade de } \\
\text { produtos }\end{array}$ & $\begin{array}{l}\text { Confiança na } \\
\text { marca }\end{array}$ \\
\hline Loja do Prazer & Muito boa & Acessível & 8 & Alta & Alta \\
\hline Miess & Muito boa & Acessível & 7 & Alta & Alta \\
\hline Aquelas coisas & Boa & $\begin{array}{l}\text { Menos } \\
\text { Acessível }\end{array}$ & 9 & Alta & Alta \\
\hline Lolla & Boa & $\begin{array}{l}\text { Menos } \\
\text { acessível }\end{array}$ & 8 & Alta & Alta \\
\hline Erosmania & Boa & Acessível & 13 & Alta & Alta \\
\hline
\end{tabular}

Quadro 7: Comparação produtos substitutos e/ou concorrentes

Fonte: Elaborado pela autora com informações dos sites (Loja do Prazer, Miess, Aquelas Coisas, Lolla e Erosmania) 


\section{Detalhamento da estratégia de entrada no mercado}

As dimensões da inovação da empresa tem como objetivo a prestação de serviços novos e diferentes, como consultorias onde os clientes possam tirar suas dúvidas sobre o universo erótico, apresentar novos artigos em feiras e chás organizados e executado da melhor maneira possível, sempre preservando a discrição e privacidade. Tais atividades serão de caráter incremental, buscando um aperfeiçoamento do que já existe no mercado.

A nossa estratégia para se inserir no mercado erótico brasileiro é trazer tudo que há de mais novo aos consumidores, direcionando este grau à sociedade. A Sex Boutique tem a pretensão de conquistar seus clientes, mostrá-los que há uma preocupação com a saúde sexual dos usuários, mostrá-los que não basta só consumir e sim saber o que consome, com a devida certificação. Todo esse esforço de inovação apresenta uma lógica vigente, já sustentada, onde a empresa buscará aperfeiçoar, incrementar e melhorar o que já existe.

\section{Formação de preço}

O preço que é um grande fator que influencia os clientes na hora da compra, pois em mercados com grandes números de concorrentes, a formação do preço muitas vezes acaba sendo mal elaborada e apresenta pouca lucratividade às empresas.

A Sex Boutique adotará uma margem de $60 \%$ sobre o custo do produto (preço de venda), sendo que aproximadamente $5,4 \%$ são de impostos sobre a mercadoria. 0 preço de vendas será baseado no custo dos produtos adquiridos.

\section{Distribuição}

A empresa atuará de forma e-commerce, sem a existência de loja física. A venda de produtos ocorrerá pelo site e também pessoalmente, permitindo o contato direto com o cliente.

A logística direcionada ao armazenamento dos produtos será feita pela responsável pela empresa e a entrega e distribuição pelos Correios, podendo futuramente realizar contratos com transportadoras para acompanhar a demanda.

\section{Promoção}

A empresa não contará com uma loja física que auxilie na promoção e dê mais visibilidade aos produtos, logo será preciso fazer uso de outros recursos para que isto ocorra.

Umas das ferramentas utilizadas serão a propaganda e a publicidade, através de redes sociais, do próprio site de vendas, em empresas parceiras. Outra forma será a venda pessoal, promovendo visitas e contato direto com o cliente. A caracterização de folders e objetos personalizados também auxiliarão esse processo de promoção. Sem descartar também, a possibilidade de brindes e cupons de descontos.

\section{Relacionamento com o cliente}

A confiança e credibilidade são valores primordiais entre a empresa e os clientes. A Sex Boutique deseja que os clientes consigam, ao visualizar a nossa marca, satisfazer suas necessidades.

Através das ferramentas digitais e do contato direto, a empresa pretende criar conteúdo que auxiliar o cliente a entender mais e melhorar sua vida sexual, usufruindo cada vez mais dos benefícios oferecidos pelos artigos eróticos.

Além do site, as informações também estarão disponíveis em artigos por e-mail, blog e redes sociais. 


\section{Finanças}

\section{Investimentos pré-operacionais}

Os investimentos pré-operacionais compreendem todos os gastos que antecedem a abertura da empresa, até a implementação do projeto. Antes mesmo que a empresa abra suas portas, há gastos com taxas de legalização, aquisições de ativo imobilizado, entre outros.

Os valores para abertura da empresa não são muito elevados nas instalações, devido ao fato de não possui loja física. O registro da marca, que é a sua propriedade intelectual e o domínio, seu endereço eletrônico são alguns dos investimentos, há também gastos com aquisições.

\begin{tabular}{|l|l|}
\hline Investimentos em obras e instalações & Período 0 \\
\hline Registro da empresa & $3.000,00$ \\
\hline Total & $3.000,00$ \\
\hline Aquisição de equipamentos e material permanente & Período 0 \\
\hline Computadores & $5.000,00$ \\
\hline Smarthphones & $5.000,00$ \\
\hline Compra de Software para emissão de NF & $2.000,00$ \\
\hline Criação do logo & 500,00 \\
\hline Mobiliário computador & $1.500,00$ \\
\hline Criação do site & $2.000,00$ \\
\hline Impressora & 500,00 \\
\hline Impressora Não Fiscal & 700,00 \\
\hline Total & $17.200,00$ \\
\hline Total & $20.200,00$ \\
\hline
\end{tabular}

Quadro 8: Investimentos iniciais

Fonte: Elaborado pela autora

\section{Projeções de receitas}

A projeção de receitas nada mais é do que a previsão do faturamento. Um planejamento, orçamento do que se espera que será o volume de vendas. Para a elaboração dessa projeção foi considerado um crescimento estimado de $14,5 \%$ ao ano do mercado, cálculo feito a partir de dados estatísticos retirados do site da Abeme. 


\section{PLANO DE EMPREENDIMENTO: SEX BOUTIQUE}

\begin{tabular}{|c|c|c|c|c|c|c|}
\hline \multicolumn{7}{|c|}{ Projeção de Receitas } \\
\hline \multicolumn{4}{|c|}{ Quantidade } & Total ANO 1 & Total ANO 2 & Total ANO 3 \\
\hline \multicolumn{4}{|c|}{ Lingeries e Fantasias } & 720 & 824,4 & 943,938 \\
\hline \multicolumn{4}{|c|}{ Masturbadores e Vibradores } & 480 & 549,6 & 629,292 \\
\hline \multicolumn{4}{|c|}{ Acessórios e Cosméticos } & 900 & 1030,5 & 1179,9225 \\
\hline \multicolumn{4}{|c|}{ Sadomasoquismo } & 480 & 549,6 & 629,292 \\
\hline \multicolumn{4}{|c|}{ Prazer anal e preservativos } & 900 & 1030,5 & 1179,9225 \\
\hline \multicolumn{4}{|c|}{ Consultoria sensual } & 120 & 137,4 & 157,323 \\
\hline \multicolumn{4}{|c|}{ Apresentações em eventos } & 60 & 68,7 & 78,6615 \\
\hline \multicolumn{4}{|c|}{ Decorações de Ambiente } & 60 & 68,7 & 78,6615 \\
\hline \multicolumn{4}{|c|}{ Demanda Total ....>〉> } & 3720 & 4259,4 & 4877,013 \\
\hline Preço & Valor & Reajuste anual & \multirow{9}{*}{ Receita de Vendas } & Total ANO 1 & Total ANO 2 & Total ANO 3 \\
\hline Lingeries e Fantasias & 100 & $10 \%$ & & $72.000,00$ & $90.684,00$ & $114.216,50$ \\
\hline Masturbadores e Vibradores & 200 & $10 \%$ & & $96.000,00$ & $120.912,00$ & $152.288,66$ \\
\hline Acessórios e Cosméticos & 50 & $10 \%$ & & $45.000,00$ & $56.677,50$ & $71.385,31$ \\
\hline Sadomasoquismo & 100 & $10 \%$ & & $48.000,00$ & $60.456,00$ & $76.144,33$ \\
\hline Prazer anal e preservativos & 130 & $10 \%$ & & $117.000,00$ & $147.361,50$ & $185.601,81$ \\
\hline Consultoria sensual & 180 & $10 \%$ & & $21.600,00$ & $27.205,20$ & $34.264,95$ \\
\hline Apresentaçōes em eventos & 800 & $10 \%$ & & $26.000,00$ & $30.228,00$ & $38.072,17$ \\
\hline Decorações de Ambiente & 400 & $10 \%$ & & $24.000,00$ & $30.228,00$ & $38.072,17$ \\
\hline \multicolumn{4}{|c|}{ Total de Vendas } & $449.600,00$ & $563.752,20$ & $710.045,90$ \\
\hline
\end{tabular}

Quadro 9: Projeção de Receitas

Fonte: Elaborado pela autora

\section{Projeção de custos e despesas}

A projeção de custos e despesas possui gastos fixos e variáveis. Por a empresa à princípio, iniciar suas atividades em menor proporção os custos e despesas são baixos, apresentando gastos maiores com a compra de mercadorias.

Custo com profissionais (seus funcionários diretamente envolvidos com a produção dos bens ou serviços)
\begin{tabular}{|c|c|c|c|c|c|c|c|}
\hline Tipo de profissional & Custo mensal? & Salário & $\%$ de encargos & Quantidade & Total ANO 1 & Total ANO 2 & Total ANO 3 \\
\hline Consultoras Sensuais & Sim & $\mathbf{1 . 2 0 0 , 0 0}$ & $54 \%$ & 2 & $46.752,00$ & $46.752,00$ & $46.752,00$ \\
\hline Total de Custos com Pessoal & & & & & $46.752,00$ & $46.752,00$ & $46.752,00$ \\
\hline
\end{tabular}

Quadro 10: Custos com profissionais

Fonte: Elaborado pela autora 


\begin{tabular}{|c|c|c|c|}
\hline \multicolumn{4}{|l|}{ Projeção de custos } \\
\hline Custos com produtos & Total ANO 1 & Total ANO 2 & Total ANO 3 \\
\hline Lingeries e Fantasias & $36.000,00$ & $41.400,00$ & $47.610,00$ \\
\hline Masturbadores e Vibradores & $36.000,00$ & $41.400,00$ & $47.610,00$ \\
\hline Acessórios e Cosméticos & 24.0 & $27.600,00$ & $31.740,00$ \\
\hline Sadomasoquismo & 0,00 & $13.800,00$ & 0,00 \\
\hline Prazer anal e preservativos & $6.000,00$ & $6.900,00$ & $7.935,00$ \\
\hline Total & $114.000,00$ & $131.100,00$ & $150.765,00$ \\
\hline Custos com serviços & Total ANO 1 & Total ANO 2 & Total ANO 3 \\
\hline Consultoria sensual & 840,00 & 966,00 & $1.110,90$ \\
\hline Apresentações em eventos & 4.2 & 4.8 & 4,50 \\
\hline Decorações de Ambiente & 2.10 & 2.4 & $2.777,25$ \\
\hline To & $7.140,00$ & $8.211,00$ & $9.442,65$ \\
\hline Total & $121.140,00$ & $139.311,00$ & $160.207,65$ \\
\hline
\end{tabular}

Quadro 11: Projeção de custos

Fonte: Elaborado pela autora

\begin{tabular}{l} 
Despesas com pessoal (profissionais da área administrativa e de atividades de apoio) \\
\begin{tabular}{|c|c|c|c|c|c|c|}
\hline Tipo de profissional & Salário & $\%$ de encargos & Quantidade & Total ANO 1 & Total ANO 2 & Total ANO 3 \\
\hline Auxiliar de escritório & $1.200,00$ & $54 \%$ & 2 & $46.752,00$ & $46.752,00$ & $46.752,00$ \\
\hline
\end{tabular} \\
\hline
\end{tabular}

Quadro 12: Despesas com pessoal

Fonte: Elaborado pela autora

\begin{tabular}{|c|c|c|c|c|c|}
\hline \multicolumn{6}{|l|}{ Projeção das Despesas Gerais } \\
\hline Administrativas e de escritório & Item mensal? & Valor mensal & Total ANO 1 & Total ANO 2 & Total ANO 3 \\
\hline Telefone & Sim & 200,00 & $2.400,00$ & $2.400,00$ & $2.400,00$ \\
\hline Papelaria & Não & 200,00 & 0,00 & 0,00 & 0,00 \\
\hline Recarga de Cartucho & Sim & 50,00 & 600,00 & 600,00 & 600,00 \\
\hline \multicolumn{3}{|c|}{ Total } & $3.000,00$ & $3.000,00$ & $3.000,00$ \\
\hline Marketing e comercialização & Item mensal? & Valor mensal & Total ANO 1 & Total ANO 2 & Total ANO 3 \\
\hline Manutenção Site & Sim & 200 & $2.400,00$ & $2.400,00$ & $2.400,00$ \\
\hline Domínio E-mail & Não & 400 & 0,00 & 0,00 & 0,00 \\
\hline Propaganda e Publicidade & Sim & 500 & $6.000,00$ & $6.000,00$ & $6.000,00$ \\
\hline \multicolumn{3}{|c|}{ Total } & $8.400,00$ & $8.400,00$ & $8.400,00$ \\
\hline Serviços de terceiros & Item mensal? & Valor mensal & Total ANO 1 & Total ANO 2 & Total ANO 3 \\
\hline Contador & Sim & 400 & $4.800,00$ & $4.800,00$ & $4.800,00$ \\
\hline Correios & Sim & 2000 & $24.000,00$ & $24.000,00$ & $24.000,00$ \\
\hline \multicolumn{3}{|c|}{ Total } & $28.800,00$ & $28.800,00$ & $28.800,00$ \\
\hline Outras despesas & Item mensal? & Valor mensal & Total ANO 1 & Total ANO 2 & Total ANO 3 \\
\hline Treinamento Consultoras & Não & 3000 & 0,00 & 0,00 & 0,00 \\
\hline \multicolumn{3}{|c|}{ Total } & 0,00 & 0,00 & 0,00 \\
\hline \multicolumn{2}{|l|}{ Total das Despesas } & & $40.200,00$ & $40.200,00$ & $40.200,00$ \\
\hline
\end{tabular}

Quadro 13: Projeção das Despesas Gerais

Fonte: Elaborado pela autora 


\section{Impostos e contribuições}

Os impostos que a empresa terá que arcar são com vendas de produtos e prestação de serviços, por está enquadrada na tributação de Simples Nacional a mesma pagará uma única guia, onde já haverá as devidas retenções de ICMS, PIS, COFINS, IRPJ E CSLL.

Quanto a folha de pagamento, há o recolhimento do INSS e do FGTS mensalmente, o que também já foi apropriado a tabela de custos com profissionais.

\begin{tabular}{|c|c|}
\hline Base de cálculo para impostos & $\%$ \\
\hline Percentual médio de impostos pagos sobre a venda de produtos & $8 \%$ \\
\hline Percentual médio de impostos pagos sobre a venda de serviços & $5 \%$ \\
\hline
\end{tabular}

Quadro 14: Base de cálculo para impostos

Fonte: Elaborado pela empresa

\section{Resultados}

\begin{tabular}{|c|c|c|c|}
\hline \multicolumn{4}{|c|}{ Projeção de resultados } \\
\hline & Ano 1 & Ano 2 & Ano 3 \\
\hline Receita Bruta Total & $449.600,00$ & $563.752,20$ & $710.045,90$ \\
\hline Lingeries e Fantasias & $72.000,00$ & $90.684,00$ & $114.216,50$ \\
\hline Masturbadores e Vibradores & $96.000,00$ & $120.912,00$ & $152.288,66$ \\
\hline Acessórios e Cosméticos & $45.000,00$ & $56.677,50$ & $71.385,31$ \\
\hline Sadomasoquismo & $48.000,00$ & $60.456,00$ & $76.144,33$ \\
\hline Prazer anal e preservativos & $117.000,00$ & $147.361,50$ & $185.601,81$ \\
\hline Consultoria Sensual & $21.600,00$ & $27.205,20$ & $34.264,95$ \\
\hline Apresentação em eventos & $26.000,00$ & $30.228,00$ & $38.072,17$ \\
\hline Decoração de Ambiente & $24.000,00$ & $30.228,00$ & $38.072,17$ \\
\hline (-) Impostos e deduções sobre vendas & $29.367,00$ & $36.874,38$ & $46.443,28$ \\
\hline Receita Líquida & $420.233,00$ & $526.877,82$ & $663.602,61$ \\
\hline (-) Custos dos produtos e serviços & $167.892,00$ & $186.063,00$ & $206.959,65$ \\
\hline Margem de Contribuição & $252.341,00$ & $340.814,82$ & $456.642,96$ \\
\hline Margem (\%) & $56 \%$ & $60 \%$ & $64 \%$ \\
\hline Despesas & $86.952,00$ & $86.952,00$ & $86.952,00$ \\
\hline Despesas administrativas e de escritório & $3.000,00$ & $3.000,00$ & $3.000,00$ \\
\hline Despesas de marketing e comercialização & $8.400,00$ & $8.400,00$ & $8.400,00$ \\
\hline Despesas com serviços de terceiros & $28.800,00$ & $28.800,00$ & $28.800,00$ \\
\hline Outras despesas & 0,00 & 0,00 & 0,00 \\
\hline Despesas com Pessoal & $46.752,00$ & $46.752,00$ & $46.752,00$ \\
\hline Lucro Bruto & $165.389,00$ & $253.862,82$ & $369.690,96$ \\
\hline (-) Impostos s/ Lucro & 0,00 & 0,00 & 0,00 \\
\hline Lucro Líquido & $165.389,00$ & $253.862,82$ & $369.690,96$ \\
\hline
\end{tabular}

Quadro 15 :Resultados

Fonte: Elaborado pela autora 


\section{Fluxo de Caixa}

\begin{tabular}{|c|c|c|c|c|}
\hline \multicolumn{5}{|l|}{ Fluxo de caixa } \\
\hline Entradas & Período 0 & Total ANO 1 & Total ANO 2 & Total ANO 3 \\
\hline Receitas & & $449.600,00$ & $563.752,20$ & $710.045,90$ \\
\hline Total & 0,00 & $449.600,00$ & $563.752,20$ & $710.045,90$ \\
\hline Saídas & Período 0 & Total ANO 1 & Total ANO 2 & Total ANO 3 \\
\hline Deduçōes & & 0,00 & 0,00 & 0,00 \\
\hline Impostos sobre as vendas de produtos & & $20.880,00$ & $26.298,36$ & $33.122,78$ \\
\hline Impostos sobre as vendas de serviços & & $8.487,00$ & $10.576,02$ & $13.320,50$ \\
\hline Impostos sobre o lucro & & 0,00 & 0,00 & 0,00 \\
\hline Custos totais & & $167.892,00$ & $186.063,00$ & $206.959,65$ \\
\hline Despesas totais & & $86.952,00$ & $86.952,00$ & $86.952,00$ \\
\hline Investimentos & $20.200,00$ & 0,00 & 0,00 & 0,00 \\
\hline Total & $20.200,00$ & $284.211,00$ & $309.889,38$ & $340.354,93$ \\
\hline Fluxo de caixa líquido & $-20.200,00$ & $165.389,00$ & $253.862,82$ & $369.690,96$ \\
\hline Fluxo de caixa acumulado & $-20.200,00$ & $145.189,00$ & $399.051,82$ & $\mathbf{7 6 8 . 7 4 2 , 7 8}$ \\
\hline
\end{tabular}

Quadro 16: Fluxo de Caixa

Fonte: Elaborado pela autora

\section{Análise de Investimento}

\section{Taxa Interna de Retorno (TIR) e Valor Presente Líquido (VPL)}

A análise de investimentos considera a viabilidade de abrir um negócio. Um dos critérios para que 0 empreendedor queira investir em um negócio pode ser o uso de ferramentas como a taxa interna de retorno (TIR), o valor presente líquido (VPL) e o payback.

A taxa interna de retorno iguala o valor presente do somatório das receitas líquidas futuras ao valor do investimento. Dessa forma, quanto maior a TIR, maior a probabilidade de um investimento ser considerado viável. Já o valor presente líquido, considera a mudança do valor do dinheiro no tempo. Neste caso, para um investimento ser aceito o VPL precisa ser positivo.

\begin{tabular}{|l|l|}
\hline \multicolumn{2}{|l|}{ FLUXO DE CAIXA LÍQUIDO } \\
\hline Investimento & $-\mathrm{R} \$ 20.200,00$ \\
\hline Ano 1 & $\mathrm{R} \$ 165.389,00$ \\
\hline Ano 2 & $\mathrm{R} \$ 253.862,82$ \\
\hline Ano 3 & $\mathrm{R} \$ 369.960,96$ \\
\hline TIR & $\mathbf{8 6 8 , 1 1 \%}$ \\
\hline VPL 15\% a.a & $\mathrm{R} \$ \mathbf{5 7 9 . 0 2 8 , 6 2}$ \\
\hline
\end{tabular}

Quadro 17: Fluxo de Caixa Líquido

Fonte: Elaborado pela autora 


\begin{tabular}{|l|l|}
\hline \multicolumn{2}{|l|}{ FLUXO DE CAIXA ACUMULADO } \\
\hline Investimento & $-\mathrm{R} \$ 20.200,00$ \\
\hline Ano 1 & $\mathrm{R} \$ 145.189,00$ \\
\hline Ano 2 & $\mathrm{R} \$ 399.051,82$ \\
\hline Ano 3 & $\mathrm{R} \$ 768.742,78$ \\
\hline TIR & $864,49 \%$ \\
\hline VPL 15\% a.a & $\mathrm{R} \$ 933.452,67$ \\
\hline
\end{tabular}

Quadro 18: Fluxo de Caixa Acumulado

Fonte: Elaborado pela autora

\section{Payback}

O payback é a ferramenta utilizada para a análise do investimento, que determina quanto tempo é necessário para que a empresa recupere o valor investido. Ele indica o risco do negócio, pois quanto mais alto o payback, maior a vulnerabilidade às intempéries do mercado.

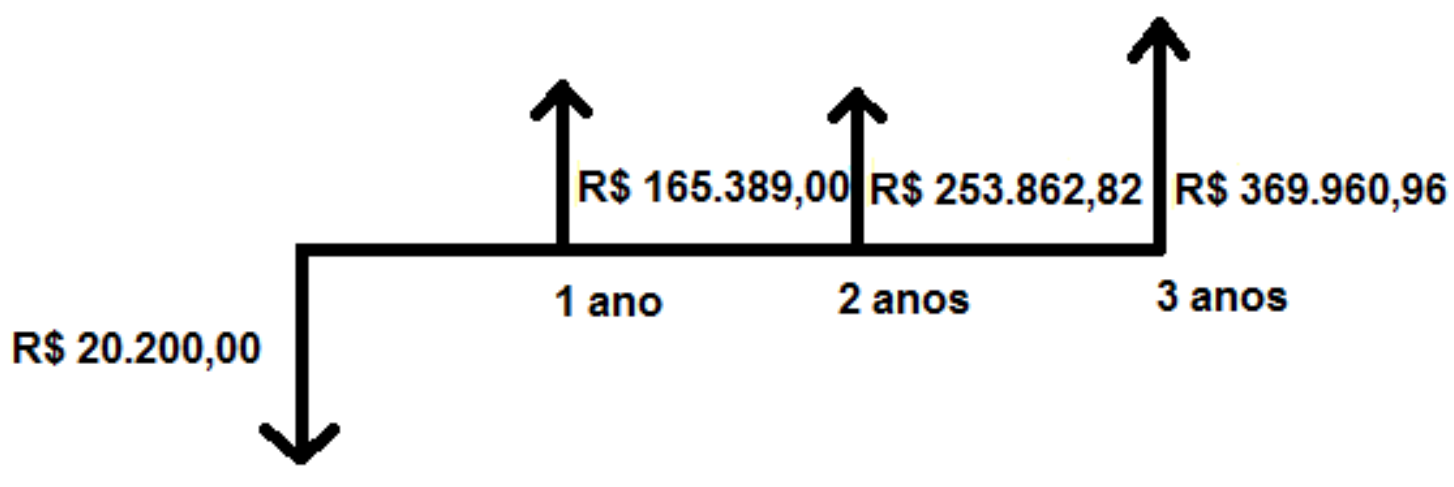

Figura 7: Payback

Fonte: Elaborado pela autora

Conclui-se que o payback se dá no primeiro ano de empresa, mais precisamente no segundo mês, de acordo com receita apurada e custos e despesas abatidas.

\section{Ponto de Equilíbrio}

O Ponto de Equilíbrio, também conhecido como Break-Even Point, Ponto Crítico ou Ponto de Ruptura, é o momento em que a empresa tem suas vendas igualadas aos valores de suas despesas, não obtendo nem lucro nem prejuízo. Ou seja, o faturamento mínimo para cobrir seus custos (fixos e variáveis).

Há uma fórmula para realizar o cálculo, onde: 
Ponto de Equilíbrio = (Custo Fixo) $x 100$

(Receita - Custo Variável)

Lembrando que:

Margem de Contribuição = Receita - Custo Variável

Margem de Contribuição $=R \$ 420.233,00-R \$ 167.892,00$

Margem de Contribuição $=\underline{\mathrm{R} \$ 252.341,00} \quad$ X $100=56 \%$

$\mathrm{R} \$ 449.600,00$

Com os valores da Sex Boutique:

Ponto de Equilíbrio $=\underline{\mathrm{R} \$ 86.952,00}$

$56 \%$

Ponto de Equilíbrio $=\mathrm{R} \$ 48.693,12$

$O$ ponto de equilíbrio encontrado significa que a empresa precisará ter um faturamento de $\mathrm{R} \$ 48.693,12$ (quarenta e oito mil, seiscentos e noventa e três reais e doze centavos) para cobrir todos os custos e despesas fixos e variáveis sem ter lucro ou prejuízo.

\section{Necessidade de recursos e formas de obtenção}

Analisando o planejamento financeiro, o volume de vendas apresenta valores significativos. O que significa que a projeção de receitas é positiva, não sendo necessário a busca por novos recursos. É um investimento maior em mercadorias, pois trata-se de um modelo e-commerce, tendo poucos gastos com instalações.

\section{Bibliografia}

DORNELAS, José Carlos Assis. Empreendedorismo: transformando ideis em negócios. 6. ed. Rio de Janeiro: Campus, 2001. Documento digital em formato PDF disponível em <http://www.josedornelas.com.br/wp-content/uploads/2013/10/emp-degustacao.pdf>.

CHIAVENATO, Idalberto. Empreendedorismo: dando asas ao espírito empreendedor: empreendedorismo e viabilidade de novas empresas. 2. ed. rev. e atualizada. São Paulo: Saraiva, 2007. Documento digital em formato PDF disponível em <http://www.sincorpr.org.br/arquivos_pdf/empreendendorismo.pdf>.

DOLABELA, Fernando. Oficina do Empreendedor, Cultura Editores Associados São Paulo, 1999.

DOLABELA, Fernando. 0 segredo de Luísa. Rio de Janeiro: Sextante, 2008.

DORNELAS, J. C. A. Empreendedorismo Corporativo. $1^{\text {a }}$ ed. Rio de Janeiro: Editora Elsevier, 2003.

MALHOTRA, Naresh k. Introdução à pesquisa de marketing. Tradutor Robert Brian Taylor. São Paulo: Pearson Prentice Hall, 2005.

NERI, Marcelo. Novo Mapa das Religiões. Rio de Janeiro: FGV, CPS, 2011. Documento digital disponível em PDF em <http://www.cps.fgv.br/cps/religiao/>. Acesso em: 08 de junho de 2017. 